\title{
The Control Methods used by the Local Farmers to reduce Weaver-Bird Raids in Tiko Farming Area, Southwest Region, Cameroon
}

\author{
Melle Ekane Maurice*, Nkwatoh Athansius Fuashi, Ngongpan Honourine Mengwi, Esong Lionel Ebong, \\ Pen David Awa and Njonguo Funjuh Daizy \\ Department of Environmental Science, Faculty of Science, University of Buea, Southwest Region, Cameroon
}

\section{Article Info \\ *Corresponding author: Melle Ekane Maurice \\ Department of Environmental Science Faculty of Science \\ University of Buea \\ P.O.Box 63, Southwest Region \\ Cameroon \\ E-mail: melleekane@gmail.com}

Received: February 13, 2019

Accepted: March 4, 2019

Published: March 12, 2019

Citation: Maurice ME, Fuashi NA, Mengwi $\mathrm{NH}$, Ebong EL, Awa PD, Daizy NF. The Control Methods used by the Local Farmers to reduce Weaver-Bird Raids in Tiko Farming Area, Southwest Region, Cameroon. Madridge J Agric Environ Sci. 2019; 1(1): 31-39. doi: $10.18689 /$ mjaes-1000106

\begin{abstract}
Copyright: @ 2019 The Author(s). This work is licensed under a Creative Commons Attribution 4.0 International License, which permits unrestricted use, distribution, and reproduction in any medium, provided the original work is properly cited.
\end{abstract}

Published by Madridge Publishers

\begin{abstract}
One of the most common conflicts between people and wildlife takes the form of crop-raiding, a problem that has created severe crop-yield decline in sub Saharan Africa. The main objective of this survey was to investigate the various methods used by the local farmers in Tiko farming area against weaver-bird raids. The research data was collected through the administration of 250 questionnaires to a chosen population of farmers in the study area. The results have revealed a positive significance between crop-raiding and the various methods used to control the weaver-birds pest, $\chi^{2}=7.592, d f=6, P<0.05$. More so, there is a positive significance between the age-class and the various methods used to control weaver-birds' population in Tiko farmland, $\chi^{2}=21.207, d f=18, P<0.05$. The study has also revealed a significance on the individuals involved in pest management $\chi^{2}=50.115$, $\mathrm{df}=24, \mathrm{P}<0.05$. In addition, the study recorded a significance between challenges faced in crop-production and pests problems, $\chi^{2}=9.960, d f=3, P<0.05$. The study has shown a positive significance on the seasonal pests management cost and the period of cropraiding, $\chi^{2}=9.454, d f=6, P<0.05$. This study has revealed the use of many methods by the local farmers in Tiko farming area to prevent the weaver-bird population from growing. Though, most of these methods are local and produce very little results on the fields, the farmers are yet to learn and master modern methods. The application of poisonous pesticides in fighting the weaver-bird raids in crop farmlands in Tiko as indicated by some respondents should be avoided for the welfare of the entire ecosystem.
\end{abstract}

Keywords: Wildlife; Crop-raiding; Local farmers; Farming area; Weaver-bird population.

\section{Introduction}

All over the world, fauna and flora are suffering from the ravages of man's insatiable need for more land on which to live and grow food. Birds can inflict damage to the crops and a loss to the farmers in all the stages of crops right from sowing, planting until harvesting. Weaver-birds are among the biotic constraints that caused decline in the yield potential of irrigated lowland rice from potential yield of $5 \mathrm{t} \mathrm{ha}^{-1}$ to an average yield of $2.8 \mathrm{t} \mathrm{ha}^{-1}$ [1]. They are often locally abundant and are major pests on farms [2] and major pests of rice in Badeggi, Niger State, Nigeria [3]. Traditional methods usually rely on scaring birds by merely deflecting the birds to neighbouring growing crops, a common but costly management strategy [4]. Long term studies of weaver birds' seasonal population fluctuations had suggested that the farmer could plan his cropping calendar to avoid planting that would prevent crop fruiting when the weaver-bird pest population was high [5]. Information of farmers' perceptions of the ecology, pest status and their current weaver-birds pest control methods can make an important contribution 
to this study. Studies examining specifically, perceptions and management practices of Cameroonian crop-farmers are rare. Farmers' perception, belief and management strategies therefore need to be documented [6] for they are thought to influence the success of pest management practices compared to other factors. The socioeconomic conditions and culture of farmers are thought to influence the success of weaver-bird pest management practices compared to other factors, such as the technology availability to manage the pest problem [7]. Gaps have been known to exist in farmers' indigenous knowledge of pest biology and ecology [8]. Therefore studies of farmers' knowledge of pest management should be appraised and their perception as well as identify gaps in their knowledge and areas where scientists and extension agents could provide vital inputs to assist farmers. The objective of this study was to explore the various methods used by the local farming population of Tiko to protect their crop farmlands from weaver-bird raids.

The world population continues to grow, accompanied by rapid urbanization and industrialization. In 2009, more than $50 \%$ of the world's population was living in cities [9], with the most rapid urban growth in low-income regions. In Africa the urban population is likely to triple, and in Asia it will be more than double in a few decades [9]. Loss of biodiversity is a worldwide phenomenon [10]. Even though cities only occupy $2.7 \%$ of the world's drylands, urbanization leads to several environmental problems including damage to biodiversity [11]. Birds are globally seen as a flagship group for conservation, for eco-logical, evolutionary reasons, and they occupy a significant place in people's perception of nature. Birds are highly sensitive as well as mobile, and thus eminently suitable to study the impact of anthropogenic disturbance on biodiversity [12].

The activity pattern of birds in croplands is influenced by a number of factors such as crop type, non-crop physical structural arrangement and the agricultural practices [13]. Shift in cultivation timing also significantly affects the activity pattern of cropland birds, which causes further reduction of the population of farmland birds [14]. An annual shift in the cultivation timing in India is dependent on the onset of the monsoon. The rainfall period affects bird breeding activities, habitat formation and food availability. In spite of the natural and atmospheric conditions, the increase in land use by humans for purposes other than agriculture influences bird habitat degradation rate, as these birds are sensitive to the changing pattern of agricultural practices [15]. Cropland birds have significantly adapted to the dynamic nature due to their unique metabolism and non-selective food habit [16]. There has been an enormous deterioration in bird populations in the last 30 years and consequently many farmland birds are listed as endangered species [17]. Considerable measures are required to protect bird biodiversity [18]. The trend of reduction in cropland area, agricultural intensity and bird biodiversity is not only common in Asia [19], but research in other parts of the world such as North America [20], Europe [21] and Africa [22] also show an identical scenario.
The extensive use of pesticides in agriculture influences bird health causing endocrine disruption and weakening of the immune mechanism of bird species dwelling in the croplands, and hence it has destructive biological effect on the birds [23]. Pesticide residues have been reported in eggs of many bird species in different parts of the world [24]. Recent study in Iran indicates that organochlorine pesticide and polychlorinated biphenyl (PCB) residues are found in bird's feathers [25] and there are many pesticides which are noted to be more harmful to birds than to mammals [26]. In addition, pesticide coated seeds create risk of toxicity and pesticide poisoning [27].

However, there are few studies of the problem among the farmers and the magnitude of crop damage caused by birds in India [28]. The greatest damage to the matured crops was observed due to the foraging activities of bird species like Baya Weavers Ploceus philippinus and Munias Lonchura spp. and House Crows Corvus splendens with an overall reduction of crop yield by more than 55\% [29]. For aging pattern of birds depend more on their behavior with reference to predators locations rather than the status of feeding source. In addition to these species, the Rose-ringed Parakeet Psittacula krameri is the most common and destructive bird from agricultural perspective which inflicts huge damage to standing cereal crops, fruit orchards and vegetable crops [30]. A single Roseringed Parakeet Psittacula krameri consumes about $15 \mathrm{~g}$ of sunflower seeds per day. Birds like Common Myna Acridotheres tristis, Jungle Myna Acridotheres fuscus, Brahminy Starling Sturnus pagodarum, House Crow Corvus splendens and Whitecheeked Bulbul Pycnonotus leucotis damage the fruit crops especially of grapes to a great extent in Himachal Pradesh, India [31]. These depredation are not only limited to loss of yield but also affects the quality of grapes, which in turn reduces the quality of the wine, thus for aging activities of birds causes a decrease in overall agricultural productivity. In Gujarat, Sarus Crane (Grus antigone) is considered as one of the pests by farmers and it causes damage in the range of 0.2 to $13.6 \%$ to the paddy crops. However it is a globally threatened species and it was found that its population is declining at an alarming rate [32].

\section{Materials and Methods}

\section{Description of the study area}

Tiko Municipality is found in the Southwest Region of Cameroon. With a geographic location of Longitude $9^{\circ} 21^{\prime} 36.18^{\prime \prime}$ E and Latitude $4^{\circ} 04^{\prime} 30.00^{\prime \prime} \mathrm{N}$, it has a total surface area of 4,840 $\mathrm{km}^{2}$ and is bounded to the West by Limbe, to the North by Buea, to the East by Muyuka, and to the South by Dibombari town respectively, [33]. Climatically, Tiko has two distinct seasons, a long rainy season of about 8 months and a short dry season of about 4 months. The annual amount of rainfall ranges from $2000 \mathrm{~mm}$ to $4000 \mathrm{~mm}$, providing a suitable condition for both perennial and annual crops to grow, an ideal condition for two cropping seasons a year. Daily temperatures are high throughout the year ranging from $28^{\circ} \mathrm{C}$ to $33^{\circ} \mathrm{C}$, with a moderately variable atmospheric humidity throughout the year. The drainage system of Tiko includes mainly river Mungo, 
Ombe stream, Ndongo stream and the sea [33]. About $80 \%$ of the forest land of Tiko municipality has been converted into oil palm, rubber and banana plantations by the Cameroon Development Corporation (CDC). The creeks harbor large areas of mangrove forest which is very highly exploited for wood. These mangrove swamps form important breeding sites for fish, shrimp and other important aquatic wildlife. The clearing of forest for farmlands has destroyed the habitat of many wildlife species, rendering them vulnerable to hunters. This has led to the disappearance of many forest wildlife species like antelopes, and African Buffalos. However, a few wildlife species such as guenon monkeys, python, bush-pigs, and crocodiles are still observed [33] (Figure 1).

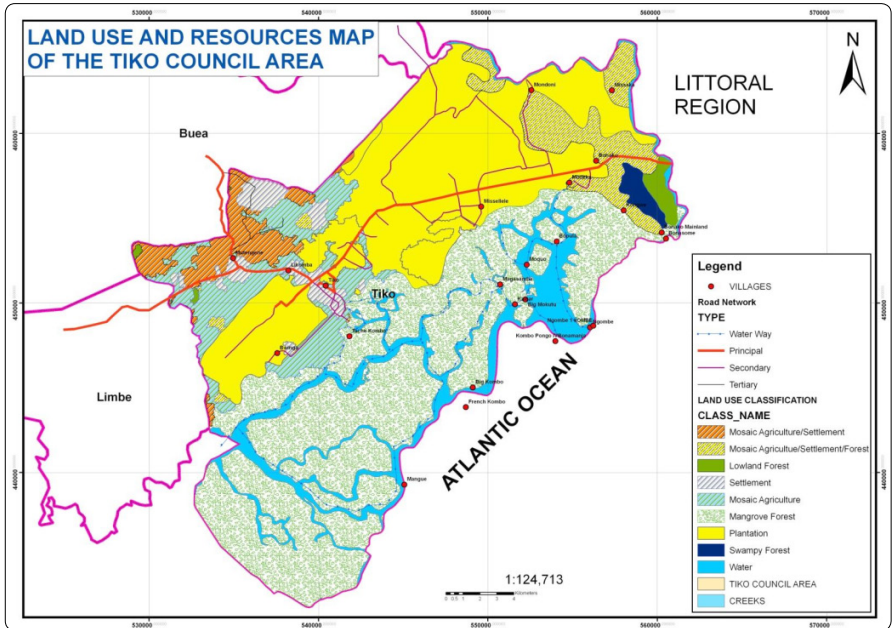

Figure 1. Map of Tiko Municipality (Source: SIRDEP 2011).

\section{Data collection and analysis}

The research data of this study was collected through the administration of 250 questionnaires to a chosen population of farmers in the study area. With the help of a field assistant almost all the questionnaires given to the respondents were collected within one week. During this survey, variables such as crop-raids, age class of respondent, pest management, crop-yield challenges, and seasonal pest management cost were tested on the methods used in pest control, methods of pest management, the pest problems, and the weaver-bird raiding periods respectively. The research data was analyzed by using SPSS version 20. Chi-square $\left(\chi^{2}\right)$ was the main statistical model used for inferential analysis, while the exploratory descriptive model was also used, and results have been displayed in graphs and pie-charts.

\section{Results}

The results have shown a positive significance between crop-raiding and the various methods used to control the weaver-bird pest, $\chi^{2}=7.592, \mathrm{df}=6, \mathrm{P}<0.05$ (Figure 2). The major characteristic that has contributed to the success of weaverbirds is its ability of crop-raiding in a huge population swarm, creating difficulties in managing and controlling this population at any point in time. The swarm raids in cropfarms have been the main contribution to the poor annual crop-yields farmers have suffered in raid-prone regions in Cameroon and other countries in sub Saharan Africa. In most places local farmers have devised different methods to control and manage the bird's population to harmless numbers. Though, the traditional methods used to fight these raids are yet to be modernized, however, still create an impact in the fight of population control. The local farmers have understood from past experience that with no bird population control fight, they would go home with no food and their invested labour finally becomes a painful nightmare story.

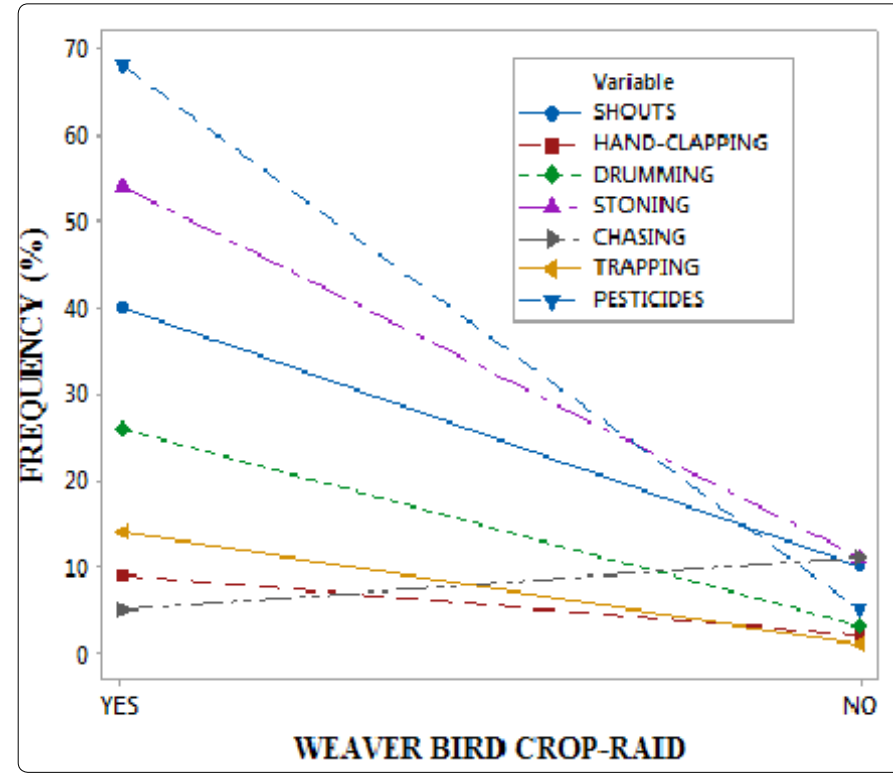

Figure 2. Crop-raiding and methods used to control the pest.

There is a positive significance between the age-class and the various methods used to control weaver-bird population in Tiko farmland, $\chi^{2}=21.207, d f=18, P<0.05$ (Figure 3). Cropfarming practice in Tiko and other parts of Cameroon is a tradition that cuts across all age-classes and gender from infancy. An average Cameroonian adult is highly equipped with different local farming methods and the ability to deal with crop-pests like weaver-birds in farmlands is no longer a new or strange phenomenon. Parents make sure crop-farming ideas and tradition are transcended down into generations through their children and grand children. Age also play a serious role in crop-farming especially in areas like Tiko where the physical strength is needed enormously for cultivation, adding more farming advantage to the adult age than any other age class.

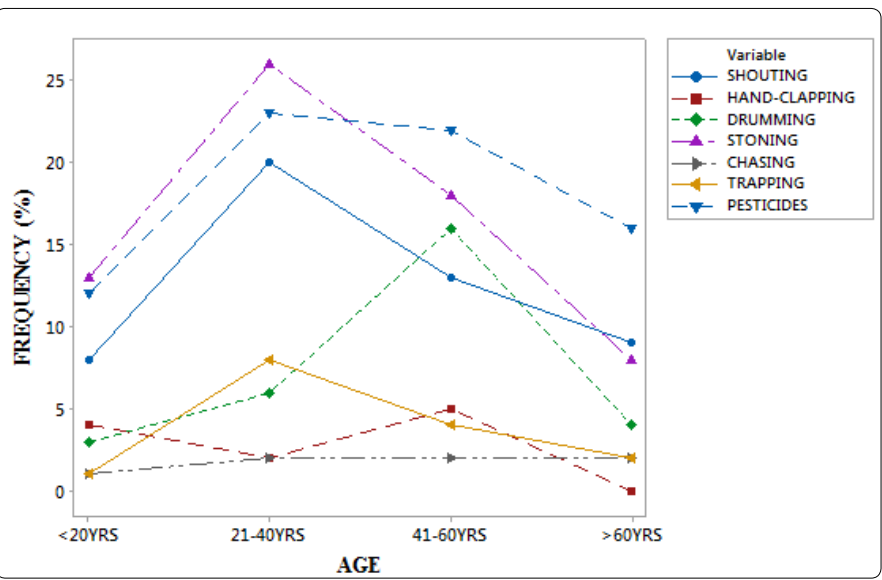

Figure 3. Age-class and the methods used in controlling the pest. 
The study also revealed a significance on the individuals involved in pest management and the methods, $\chi^{2}=50.115$, $\mathrm{df}=24, \mathrm{P}<0.05$ (Figure 4). Most farmers in the farming area of Tiko are believed to employ family members and close friends to assist them in the weaver-birds population control programs. It is an exercise that entails frequent farm-visits by the farmers for crop security, an assignment that is always considered to be best carried out by a group effort. But, in cases where social security groups cannot be formed by these farmers, the individual farmers sometimes would have to spend longer hours in the farms to ensure security for the crops from weaver-bird raids. Weaver-birds, as other social birds are very active during the early hours of the day $(6: 00$ am-11:00 am), mid-day period (12:00 am-3:00 pm), slow down activities mid day and the evening period $(4: 00 \mathrm{pm}-6: 30$ $\mathrm{pm})$ activities increase. This activity cycle is well mastered by the farmers and useful enough during farm monitoring in chasing out the birds.

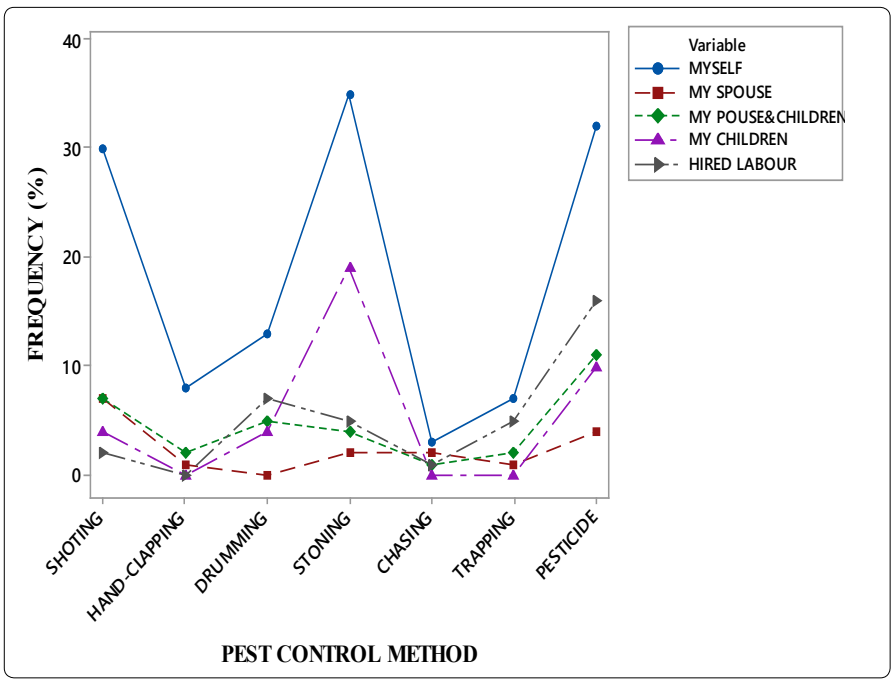

Figure 4. Pest mgt persons and the methods.

In addition, the study has revealed a significance between challenges faced in crop-production and the pests problems, $\chi^{2}=9.960, d f=3, P<0.05$ (Figure 5). The challenges faced by these farmers apart from the weaver-birds are enormous, inconsistent rainfall and other animal pests like francolins are aggravating this situation. The huge losses are already defeating subsequent farming in-puts, and if these farmers would have to be re-encouraged by any stakeholders should be by tackling the crisis of weaver-birds' population reduction within the farmlands and neighboring areas where they might temporally relocate to prepare heavy episode-raids before the farmers would make seasonal farm-harvest.

Moreso, this study revealed a positive significance on the seasonal pests management cost and the period of cropraids, $\chi^{2}=9.454, d f=6, P<0.05$ (Figure 6). In Tiko, crop-farming cost might be comparatively high due to the weaver-bird raids on farmlands, consequently to survive a persistent sustainable crop-harvest the farmers need to spend much on the pests control methods. It is believed farmers spend more in pests control in the dry seasons than the wet season, since the former is characterized with more crop-raids than the later.

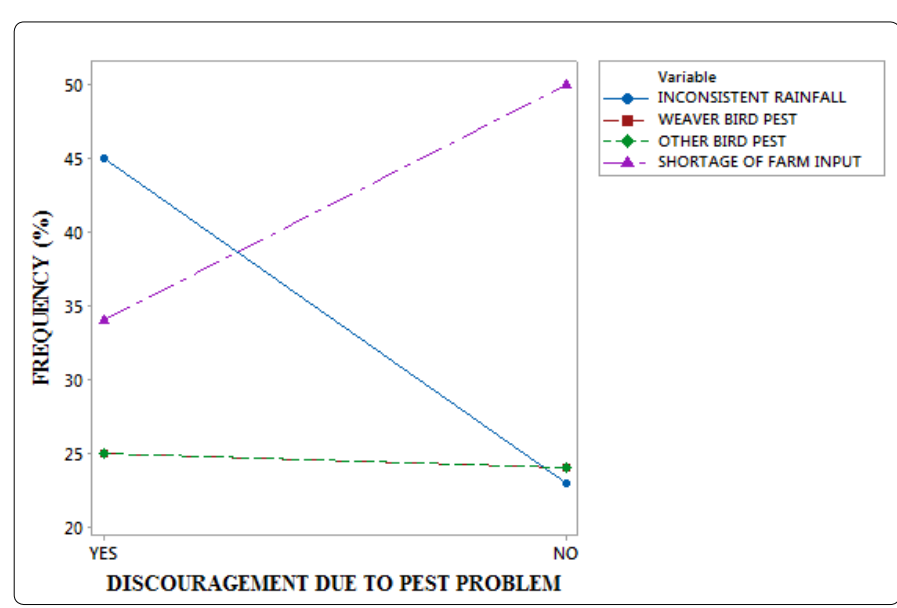

Figure 5. Challenges faced in crop-production and pest problems.

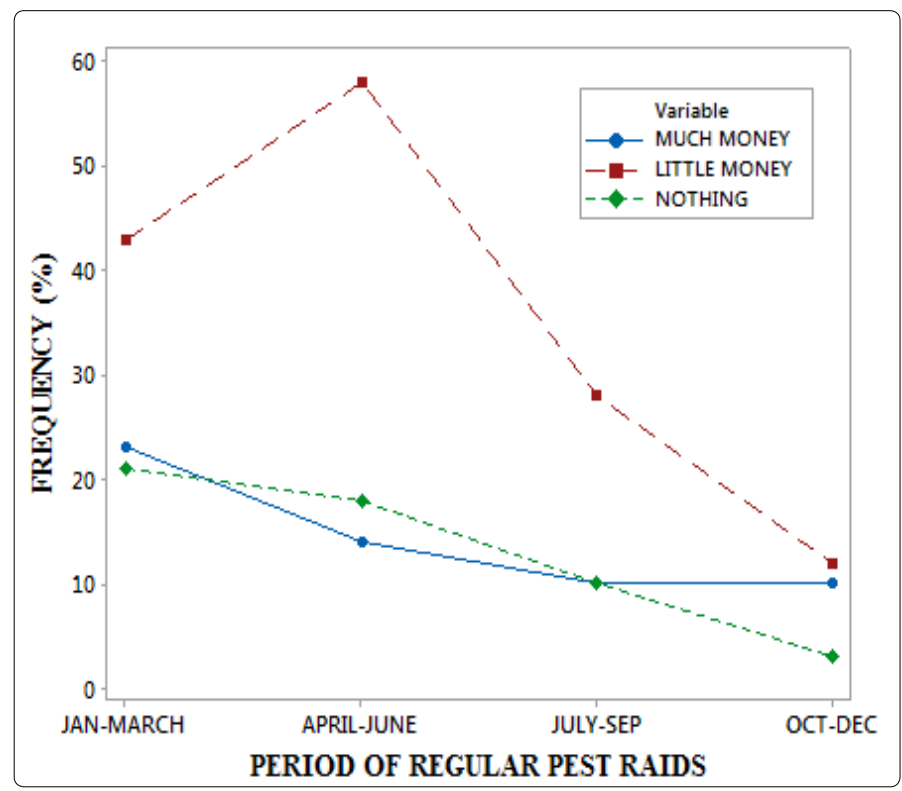

Figure 6. Seasonal pest mgt cost and the periods of raids.

The method most used by the farmers to control the population of weaver-birds in Tiko farm lands is pesticide, recording a respondent of $29.20 \%$ (Figure 7 ). The local farmers in Tiko lack the efficacy of employing conventional pest control methods like the use of chemical repellents such as trimethacarb and methiocarb known to be very effective. Nonetheless, these farmers most often resort to the use of poisonous chemicals like chlorpyrifos, a dursban organophosphate pesticide used to kill a number of pests, insects and smaller birds. Unfortunately, the application of these chemicals in farmlands creates severe side effects to the entire ecological system in the area, affecting untargeted animal species like insects needed for pollination. Sometimes rodents and snakes are also affected including aquatic animals like frogs found in neighboring water bodies which drain these croplands especially during surface runoff in the wet season. Other methods used like stone-throw to scare these birds recorded $26.00 \%$. One would consider the stoning of the bird-pest to be strenuous but in a situation where conventional methods are unaffordable this becomes a way out. This exercise needs gathering heaps of stones and placing them in different locations of the crop-farms for emergency throwing during weaver-bird raids. This is the more reason 
why most farmers use family members and friends to protect bigger farms during the day period when weaver-birds' activities are expected to be high. Nonetheless, the shouting behaviour of the farmers in farmlands as a strategy to repel bird attacks recorded a respondent of $20.00 \%$ in the study. Though, the shouting method is considered physically exhausting, ancient and securing very little results, its need and application remains a key solution in the absence of conventional methods considered expensive by the local farming population of Tiko. Drumming is another method used by the farmers to solve the problem of pest population management in farm land, and with a respondent record of $11.60 \%$ this strategy is inevitably serving a purpose. But the heavy drumming under a sunny day might mean more physical energy would be required to sustain the strategy for the whole day. Other methods like trapping, hand-clapping, and chasing of the birds recorded a respondent of $6.00 \%$, $4.40 \%$, and $2.80 \%$ respectively. The later methods used by the farmers are extremely elementary and might fail to give a good fight to the adaptive behavior of the weaver-birds.

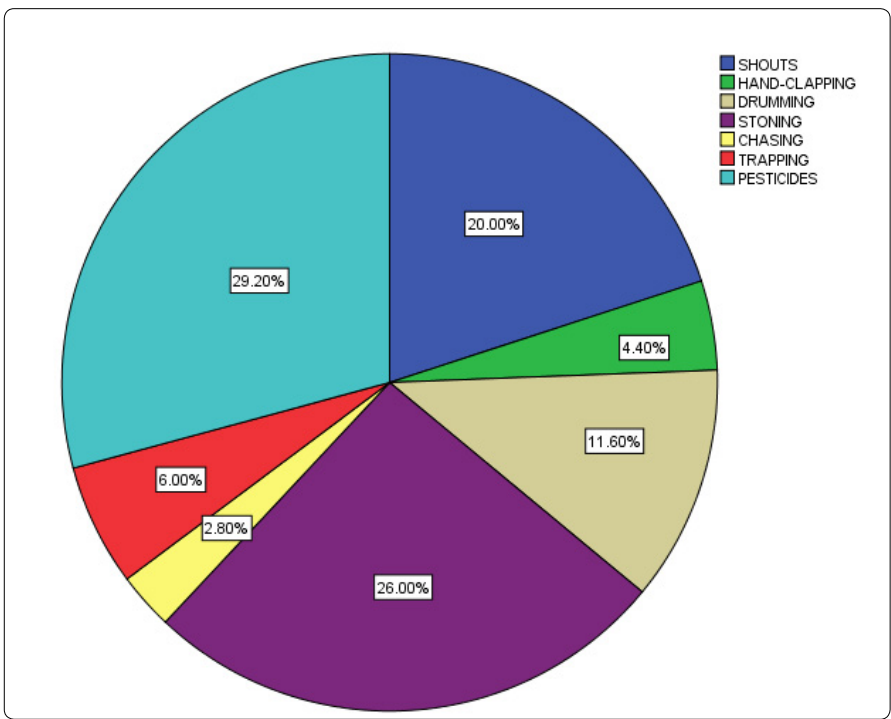

Figure.7. Methods of weaverbird control.

A respondent of $51.20 \%$ was recorded on farmers themselves monitoring their farms against the weaver-bird raids (Figure 8). It is costly for a poor local farmer to hire workers for farm surveillance against the pest birds, for this reason farmers would prefer to do the job themselves or with some family members especially their children during holidays. The fact that this monitoring exercise is tedious and time consuming most farmers would prefer to work in shift programs; each individual in the household has a day or period to take a turn. Nonetheless, farmers are believed to couple this exercise with other farm-works like clearing, planting, watering, incineration of litter, and related responsibilities which would enhance the cultivation of the same crop or other crops in the same farming area. During this period the local farmers are also known to spend a considerable amount of time in group discussions with other farmers at neighborhood, just to put their farm surveillance program into multiple uses. However, $14.40 \%$ of the respondents agreed they use hired labour for this operation. This category of farmers might be having larger farms and their target is commercializing their farm-harvest in the local food markets around Tiko and neighboring towns like Buea, Limbe and Douala.

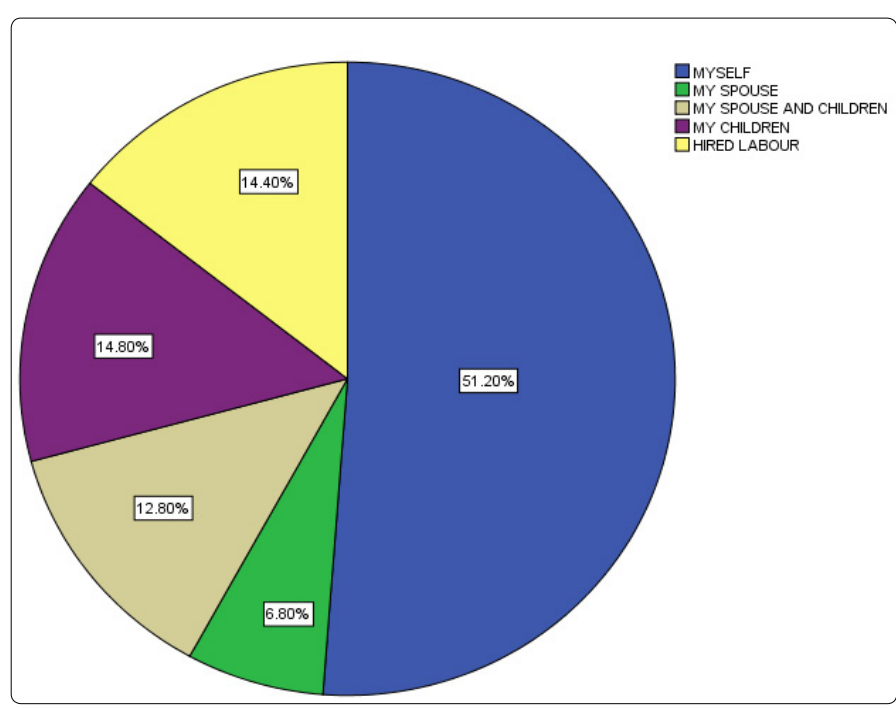

Figure 8. Farm surveillance.

A respondent of $56.40 \%$ was recorded on the consumption of weaver-birds in the study (Figure 9). Though, the weaver-birds are small in size and their meat not a traditional delicacy as compared to the bigger birds like francolins, a good number of people especially farmers enjoy their food menu. Unfortunately, the weaver-birds consumption farmers might have difficulties killing the birds for their meals; the small morphological sizes and swiftness of these birds especially in flight are among the constituted hindrances that these farmers would need to overcome. Most of the birds' killing is done by stoning roosting groups and trapping, presumably these methods have failed to reduce the number of weaver-birds in these farms. The farmers need to be equipped with modern trapping knowledge through work-shops organized by wildlife experts in teaching them how to use birdcatching nets; a strategy that if properly established would produce serious results. The local baiting traps the farmers are using presently are time consuming, and produce insignificant results. The net-trapping would kill a good number of birds within a short time, a method, if properly used would replace almost all the local primitive methods like shouting, stoning, farm-monitoring, and the use of unaccepted ecological poisonous chemicals.

A respondent of $30.80 \%$ was recorded on $51-70 \%$ average seasonal crop-yield loss by the farmers of Tiko (Figure 10). This figure is unprecedentedly high, for reasons that the national government has often echoed effective support programs to the farmers in fighting the pests through its agricultural departments at the national and regional levels. Nevertheless, it is an indication that all the educational campaigns and the extension services anchored by the national government towards this fight are with lapses. Moreover, it is time for the government of Cameroon to make modification in strategy on weaver-bird pest control in Tiko and other parts of the country. The most needed strategy might require the involvement of wildlife experts to study the ecological migration patterns and the home range of the weaver-birds. Furthermore, the population and social ecological studies of the bird-pest would 
very much lubricate this research machinery. The consequences of neglecting this ecological research strategy would mean many farmers involved in crop-cultivation like maize would start preparing for diversion into the cultivation of other crops less attacked by the weaver-birds, hence, pushing the scarcity of maize production to the edge of collapse.

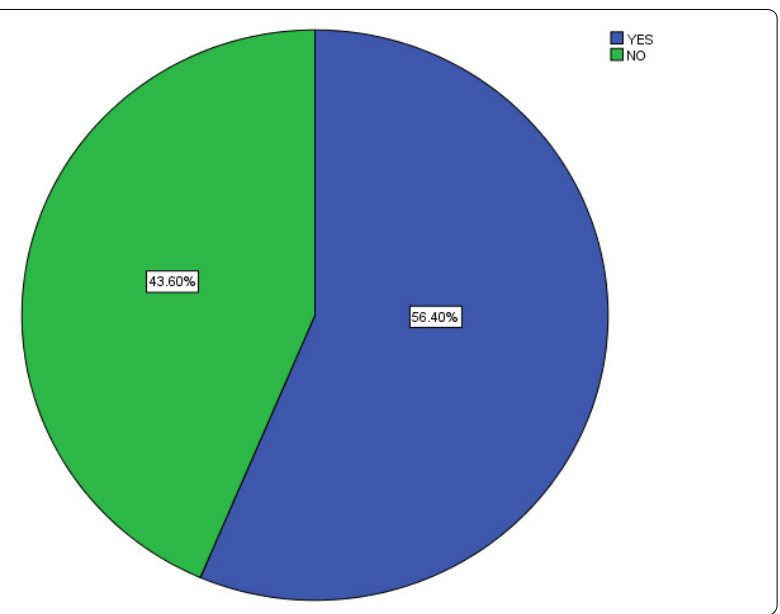

Figure 9.Wweaver bird consumption.

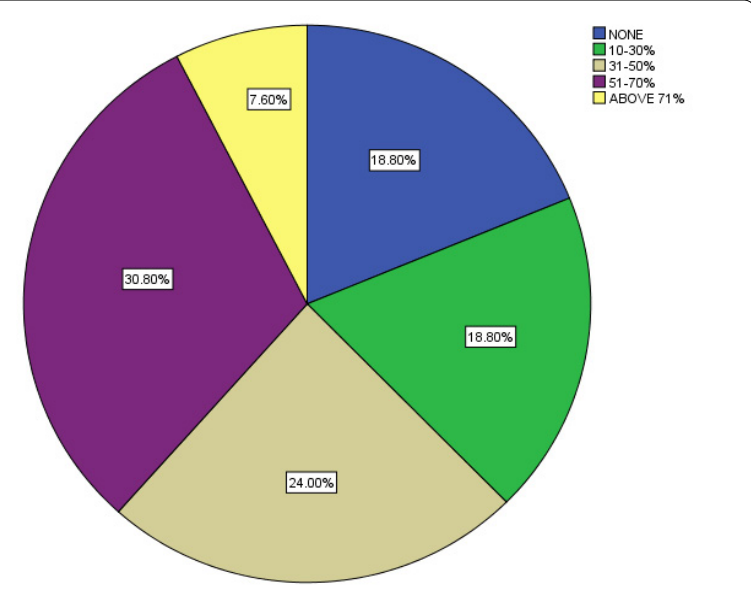

Figure 10. Average crop loss per season from weaver-birds.

\section{Discussion}

One of the most common conflicts between people and wildlife takes the form of crop-foraging, hereafter referred to as crop-raiding [34,35]. Crop raiding can be simply defined as wild animals moving from their natural habitat onto agricultural land to feed on the produce that humans grow for their own consumption [35]. This consumption of human foods regularly brings wildlife into conflict with people [36]. Crop raiding is not a new phenomenon and is as old as agriculture itself $[35,37]$. It is now widespread and an issue throughout the world [35].

Crop-raiding is essentially a foraging strategy that can be explained through optimal foraging theory - that animals strive to maximise their energy intake [38]. Raiding can be understood as a cost-benefit scenario. It is a high-risk behaviour - raiders suffer greater mortality and injuries than non-raiders [39]. However, it is also a high-gain foraging strategy - successful raiders derive substantial nutritional benefits from crops and as a result are able to reduce their overall investment in foraging time and have more time for resting and socialising [39]. As agriculture and wildlife have existed side by side for millennia, cropraiding has naturally become an essential part of many species' subsistence strategies $[40,41]$, although both Strum [42] and Riley [43] have demonstrated that crop-raiding is not inevitable when wildlife and humans live side by side.

Crop-raiding leads to reduced income for farmers and an increase in time and money spent protecting crops [44]. It is also associated with missed opportunity costs, for example, many children forgo their education to stay at home and protect crops [44], while protection also places a considerable drain on farmers' time and may lead to reduced time to complete other work [45]. Fear of crop damage can prevent farmers from using arable land [46], while abandonment of crop fields has been reported in response to crop-raiding [47]. As well as reduced profits for farmers, crop damage leads to increased prices for consumers and can affect development of local communities [48]. It can also affect a country's economy; for example, loss of sugar cane to wildlife in Ethiopia resulted in reduced gross product of sugar factories, in turn affecting the country's economy [49].

Farmers who grow crops especially cereals are well aware of the damage caused by birds and are generally knowledgeable about the birds which are responsible. The better known habits are those of the highly gregarious or social birds which establish noisy colonies in trees or bushes on the boundaries of crops or around the homestead. These birds are tolerated in good years when they are not inclined to feed exclusively on the crops. Noisy very active colonies can be heralding a good year both for the birds and for the farmer. Scaring the birds is usually the only option open to the subsistence farmer but other methods can be considered by the large-scale farmer keeping the birds out of the fields by direct crop protection. The alternative is to act against the birds away from the crops and this may require co-operative action. These generally involve killing the birds or their progeny. The development of large-scale farming has brought about change in the methods used to protect crops. Mechanical, chemical and electrical noise-making devices have been used to replace the traditional bird-scarer. Flame-throwers have been used to destroy nests and plant breeders have tried to breed resistance into highyielding and palatable cereal varieties. Attempts have been made to grow crops extensively in large areas [50]. The most successful methods used are aimed at targeting and killing the birds with pesticide known to be particularly toxic to birds. The pesticide are referred to as avicides and are used against the birds in their breeding colonies or night roosts (the use of avicides to kill grain-eating birds is a management strategy which can only be recommended against a concentration of no less than 25000 birds known to be feeding on a cereal crop) [51]. Non-lethal methods of protecting crops should be used against small concentrations. In most situations the farmers and the extension workers must consider all avenues open to them before resorting to methods which could be costly or environmentally threatening. 


\section{Non lethal control}

Cage: It is fully effective but it is costly. Particularly valuable crops, such as those grown on research farms for variety testing, hybrid development or seed multiplication, can be fully protected from birds by being grown in cages. They are expensive and require a wooden or metal framework supporting either wire or fabric net with a small enough mesh $(20-25 \mathrm{~mm})$ to exclude all seed-eaters. This is not a practical method for general farmers. Less effective but much less expensive is the use of fibres and nets instead of cages to keep the birds out of the crops [52].

Nets and fibres: Loose nets or synthetic fibres can be placed directly on to a crop. However, if not done carefully, the birds can still feed on the taller ears of the crop through the net. A simple structure of posts and string similar to that used in the construction of a cage but less elaborate; will give better support for the net and keep the birds away from the farms. An acrylic fibre manufactured in the form of a web-like unknotted net is retailed under the trade name Crylde. The material is teased out so that it covers the entire crop. The fibre is inexpensive when compared with the nets but is badly affected by heavy rains and strong winds which dislodge it. Removal of the material from a crop requires care if it is to be used again. It is less costly than the net and can be used for protecting any small plots of seedlings where birds' damage is a problem [53].

Bird scarers: Birds respond to sound, movement, shape, colour, touch and taste. The greatest alarm will naturally cause the bird to avoid the source of the disturbance. Taking flight and escaping is obviously the desired response to best protect the crop. Variety and irregularity of scare tactics give the best protection to the crops because continuous use of the same scaring is not effective but only work for a short time, the birds soon learn to accept the alarm and ignore it, they become habituated [54]. The simplest form of birdscaring is done by someone shouting, waving, and running through the field. In addition to shouting and waving the effective bird scarer reinforces his shouts with other noise such as the beating of empty tins or the cracking of a whip as well as hurling missiles in the form of lumps of mud or gravel at any flock of birds trying to land in the field. An excellent weapon for the bird scarer is a braided sling with the free end long and tapered in Somalia and Malawi [55]. The job of bird scaring can be made easier by the construction of a platform on top of which the scarer stands to over look the crop. The bird scarer sitting on his platform, has a line attached to the network which, when tugged, shakes the rattles and wave the flags. Pulling the line, shouting and throwing gravel or mud whenever a flock of birds approaches keep them away. This method will only fail when the birds are driven by near starvation to ignore the bird scarer [56].

Repellents: Threads and tapes, a simple and inexpensive scaring device which has been employed in certain situations such as the use of black cotton thread strung over the crop. It exploits one sense of the birds, touch, and its invisibility and, hence unexpectedness birds do not become habituated to it. Social birds emit alarm calls when they hit the thread and warn off the flock. It is less effective against ploceids. A development of this technique has been the use of flashing tapes which are stretched above the crop in parallel lines. The metallic tapes are usually silvered on one side and fluorescent on the other. The twist in the tape runs up and down it in any light breeze flashing in bright sunlight. If taut enough it also emits a noise in the wind. The tape in reality however, only involves one of the bird's senses-sight. The technique is mentioned here to emphasize the effectiveness of the 'invisible' threads to which the birds cannot habituate. The black thread is simple, cheap and more effective [57].

Sound- making devices: Techniques which exploit sound are also limited in effectiveness through habituation. Acetylene and propane exploders, called carbide guns or canons, produce loud explosions at regular intervals. Their effectiveness is increased if more than one is used. Some models rotate and change firing direction automatically. In addition, they can present a fire risk in arid areas. Expensive and variably effective noise-making instruments have also been introduced. One such is the A alarm, a battery-operated electronic amplifier which broadcasts complex intermittent sounds which can be varied in pitch and pulse [58].

Chemical repellents: Taste a version in grain-eating birds is well known in Africa particularly amongst sorghum and millet growers both of these grain crops have varieties with varying amounts of tannin in their seeds. Seeds with high tannin content are generally avoided by birds, especially if they have an alternative availability. Tannin is also less palatable to man where the bird problem is severe, resistant varieties are grown and eaten but elsewhere they are used more commonly for brewing. Chemicals which are non-toxic but unpalatable to birds can, in theory, be applied to a crop and, in theory, protect it from damage. The most promising material, methiocarb, has reduced damage to grains under experimental conditions at reasonable cost but insufficient work has been done for any specific recommendation to be made. Another use of chemical repellents is as seed dressing. One chemical tested in Africa has been the fungicide thiram [59]. Although unpromising the use of thiram as a fungicidal seed dressing may be beneficial even though it is only mildly repellent. The likelihood of a cost-effective use of chemical repellents in cereal crops is doubtful [60].

Lethal control: Killing birds in the crop is an alternative approach which is sometimes practiced by farmers. There are two ways in which the birds are killed, either by poisoning or by trapping. Quelea problem could only be solved by greatly reducing, or even eradicating, the whole population. It is now generally agreed that this strategy is impossible to achieve, uneconomical and ecologically unsound [61].

Chemical Poisoning: Much of the damage to cereals is caused around the field edge particularly in places close to cover, either trees or shrubs. A swath about 5 to $10 \mathrm{~m}$ into the crop is sprayed with a pesticide known to be toxic to 
birds. Any grain-eating bird eating the treated crop is killed. In practice however, there are major drawbacks. To be effective the pesticide must be persistent to avoid costly repeated spraying. Persistent pesticides are not permitted in grain crop close to harvest if the grain is destined for human or animal consumption. Usually the amount of crop saved, when only patches of a comparatively narrow band of the field edge are affected, is of no real consequence to the total yield, unpleasant as the damage may appear. An additional consideration is that the major cereal pests, such as the quelea, do not limit damage to the field edge but descend anywhere in the field to feed [62].

Trapping: This method has a very little effect on the crop yield unless it is a very small field which is being damaged. A large portable modified Australian Crow Trap has been used experimentally in Sudan. The trap is baited with grain and live decoy birds. The use of water as a bait has been successfully demonstrated at a quelea colony in Chad. Wire cages 1 cubic meter in size were used, with a sagging plastic sheet as the top side of the cage. A slit was made in the plastic sheet and the fledglings desperate, mistook the shimmering plastic for water. Landing on the surface, they slid inexorably through the slit into the trap and were unable to find the way out. The trap has not been used in a crop but it has potential; water is not always found close to field crops and the trap is easily made, inexpensive and reusable.

\section{Conclusion}

This study has revealed many methods used by the local farmers in Tiko farming area to prevent the weaver-birds' population from growing, though, most of these methods are local and produce very little results on the fields the farmers are yet to learn and master modern methods. The expectation that when the farmers must have acquired enough experience on the application of the conventional birds pests control methods crop-farming would gain a new height in crop cultivation revolution. But this needs national and international collaboration especially on funding support to boost the education of the farmers on the application of these conventional methods. For the lethal chemical pesticides, application should be done on croplands harboring many farms by a small jet so that even nearby bushes could be sprayed at same time to destroy their hideouts. The national government needs to take this fight seriously to guarantee future food security to the growing human population.

\section{References}

1. Singh $B N$, Fagade $S$, Ukwungwu $M N$, et al. Rice growing environments and biophysical constraints in different agro-ecological zones of Nigeria. Meteorological Journal. 1977; 21: 34-44.

2. Park PO. Granivorous bird pests in Africa. Span. 1974; 17(3): 126-112.

3. Bright EO, Ogunyemi S. Diet and foraging habits of village weaver bird Ploceus cucullatus and red-headed quelea Quelea erythrops in rice field habitats. African Journal of Plant Protection. 2000; 10: 71-81.

4. Bruggers RL. The situation of grain eating birds in Somalia. In: Proceedings of the 9th Vertebrate Pest Conference. Frenno, Carlifornia. 1980: 5-16.
5. Bright $\mathrm{EO}$, Ogunyemi S. Trends in major weaver bird numbers in the rice fields of Badeggi, Niger State, Nigeria. In: Salako FK, Lagoke STO, Aina $A B J$, Eruvbetin D, Dipeolu OA (editors). Enhancing agricultural resource base for youth development, industrial development and export. Proceedings of the 35th Annual Conference of the Agricultural Society of Nigeria, University of Agriculture, Abeokuta, Nigeria. 2001.

6. Heong KL, Escalada MM. Quantifying rice farmers' pest management decision - beliefs and subjective norms in stem borer control. Crop Prot. 1999; 18: 315-322.

7. Manikowski S. Arial spraying of quelea. Int J Pest Manag. 1988; 34(2): 133-140.

8. Bentley JW. The epistemology of plant protection: Honduran campesino knowledge of pests and natural enemies. In: Proceedings of a Seminar on Crop Protection for Resource-Poor Farmers. Natural Resource Institute. 1992; 107118.

9. Report UN. Kenya's Important Bird Areas. 2011; 1-20.

10. Butchart SHM, Walpole $M$, Collen $B$, et al. Global biodiversity: indicators of recent declines. Science. 2010; 328: 1164-1168. doi: 10.1126/science.1187512

11. Grimm NB, Faeth $\mathrm{SH}$, Golubiewski NE, et al. Global change and the ecology of cities. Science. 2008; 319: 756-760.

12. Gibson $L$, Lee $T M$, Koh $L P$, et al. Primary forests are irreplaceable for sustaining tropical biodiversity. Nature. 2011; 478: 378-383.

13. Rodenhouse NL, Best LB, Conner O, Bollinger EK. Effect of agricultural practices and farmland structure. In: Marrin TE, Finch DM (editors). Ecology and management of neotropical birds: a synthesis and review of critical issues. Oxford University Press. New Yark. 1995: 269-293.

14. Jobin B, DesGranges JL, Boutin C. Population trends in selected species of farmland birds in relation to recent developments in agriculture in the St. Lawrence Valley. Agric Ecosyst Environ. 1996; 57(2-3): 103-116.

15. Lohr SM, Gauthreaux SA, Kilgo JC. Importance of coarse woody debris to avian communities in Loblolly pine forests. Conserv Biol. 2002; 16(3): 767-777.

16. Järvinen O. Geographic gradients of stability in European land bird communities. Oecologia. 1979; 38(1): 51-69.

17. Donald PF, Sanderson FJ, Burfield IJ, Van Bommel FPJ. Further evidence of continent-wide impacts of agricultural intensification on European farmland birds, 1990-2000. Agric Ecosyst Environ. 2006; 116: 189-196.

18. Ranganathan J, Krishnaswamy J, Anand MO. Landscape-level effects on avifauna within tropical agriculture in the Western Ghats: Insights for management and conservation. Biol Conserv. 2012; 143: 2909-2917.

19. Semwal RL, Nautiyal S, Sen KK, et al. Patterns and ecological implications of agricultural land-use changes: a case study from Central Himalaya, India. Agric Ecosyst Environ. 2004; 102: 81-92.

20. Brennan LA, Kuvlesky WP. North American grassland birds: an unfolding conservation crisis? J Wildl Manage. 2005; 69: 1-13.

21. Clay J. World Agriculture and the Environment: A Commodity byCommodity Guide to Impacts and Practices. Washington D. C: World Wildlife Fund and Island Press. 2004.

22. Söderström B, Kiema S, Reid RS. Intensified agricultural land use and bird conservation in Burkina Faso. Agric Ecosyst Environ. 2003; 99: 113-124.

23. Fairbrother A, Smits J, Grasman KA. Avian immunotoxicology. J Toxicol Environ Health B Crit Rev. 2004; 7(2): 105-137.

24. Medvedev N, Lubov M. Residues of chlorinated pesticides in the eggs of Karelian birds, 1989-90. Environ Pollut. 1995; 87:65-70.

25. Behrooz RD, Esmaili-Sari A, Ghasempouri SM, Bahramifar N, Covaci A. Organochlorine pesticide and polychlorinated biphenyl residues in feathers of birds from different trophic levels of South-West Iran. Environ Int. 2009; 35(2): 285-290.

26. Walker $\mathrm{CH}$. Pesticides and birds- Mechanism of selective toxicity. Agric Ecosyst Environ. 1983; 9: 211-226.

27. Pascual JA, Hart ADM, Fryday SL. Incidence of lethal bird poisoning reduced by the regurgitation of pesticide-treated food. Environ Toxicol Chem. 1999; 18: 247-253. 
28. Dhindsa MS, Saini HK. Agricultural ornithology: an Indian perspective. Journal of Bioscience. 1994; 19: 391-402.

29. Bruggers RL, Rodriguez E, Zaccagnini ME. Planning for bird pest problems resolution: A case study. Int J Biodeterior Biodegradation. 1998; 42(2-3): 173-184.

30. Kushwaha SPS, Roy PS. Geospatial technology for wildlife habitat evaluation. Tropical Ecology. 2002; 43(1): 137-150.

31. Patyal SK, Rana RS. Bird damage to Kinnow fruits in Himachal Pradesh and evaluation of management techniques against them. Pest Management and Economic Zoology. 2006; 14(1-2): 157-161.

32. Borad CK, Mukherjee A, Parasharya BM. Damage potential of Indian Sarus crane in paddy crop agroecosystem in Kheder district of Gujarat, India. Agric Ecosyst Environ. 2001; 86(2): 211-215.

33. Society for Initiative for Rural Development and Environmental Protection (SIRDEP). The Development Plan of Tiko Council. 2011.

34. Hill CM. Conflicting attitudes towards elephants around the Budongo Forest Reserve, Uganda. Environ Conserv. 1998; 25(3): 244-250.

35. Sillero-Zubiri C, Switzer D. Crop raiding primates: Searching for alternative, humane ways to resolve conflict with farmers in Africa. People and Wildlife: A Wildlife Conservation Research Unit, Oxford University. 2001.

36. McLennan MR, Hill CM, Chimpanzee responses to researchers in a disturbed forest- farm mosaic at Bulindi, western Uganda. Am J Primatol. 2010; 72(10): 907-918.

37. Nyirenda VR, Chansa WC, Myburgh WJ, Reilly BK. Wildlife crop depredation in the Luangwa Valley, eastern Zambia. Journal of Ecology and the Natural Environment. 2011; 3(15): 481-491. doi: 10.5897/JENE11.094

38. Pyke GH. Optimal foraging theory: a critical review. Ann Rev Ecol Syst. 1984; 15: 523-575.

39. Chiyo PI, Moss CJ, Alberts SC. The influence of life history milestones and association networks on crop-raiding behavior in male African elephants. Soc Networks. 2012; 7(2): 1-11.

40. Lee PC. Sharing space: can ethnoprimatology contribute to the survival of nonhuman primates in human-dominated globalized landscapes? Am J Primatol. 2010; 72(10): 925-931. doi: 10.1002/ajp.20789

41. Wallace GE. Monkeys in maize: Primate crop-raiding behaviour and developing on-farm techniques to mitigate human-wildlife conflict. PhD, Oxford Brookes University. 2010.

42. Strum SC. The development of primate raiding: implications for management and conservation. Int J Primatol. 2010; 31(1): 133-156. doi: 10.1007/s10764-009-9387-5

43. Riley EP. The human-macaque interface: conservation implications of current and future overlap and conflict in Lore Lindu National Park, Sulawesi, Indonesia. Am Anthropol. 2007; 109(3): 473-484.

44. Marchal V, Hill CM. Primate crop-raiding: a study of local perceptions in four villages in North Sumatra, Indonesia. Primate Conservation. 2009; 24(1): 107-116.

45. Lee PC, Priston NEC. Human attitudes to primates: perceptions of pests, conflict and consequences for primate conservation. In Patterson JD, Wallis J (eds). Commensalism and Conflict: The human-primate interface. American Society of Primatologists. 2005; 1-23.
46. Wang SW, Curtis PD, Lassoie JP. Farmer perceptions of crop damage by wildlife in Jigme Singye Wangchuck National Park, Bhutan. Wildl Soc Bull. 2006; 34(2): 359-365.

47. Naughton-Treves L. Whose animals? A history of property rights to wildlife in Toro, western Uganda. Land Degrad Dev. 1999; 10(4): 311-328.

48. Loudon JE, Howells ME, Fuentes A. The importance of integrative anthropology: a preliminary investigation employing primatological and cultural anthropological data collection methods in assessing human-monkey co-existence in Bali, Indonesia. Ecological and Environmental Anthropology. 2006; 2(1): 1-13.

49. Admassu M. Damage caused by large mammals in Wonji-Shoa Sugarcane Plantation, Central Ethiopia. MSc, Addis Ababa University. 2007.

50. La Grang EM. The Kendelder mist blower as a quelea control tool. Unpublished Government Reports Department of National parks and wild life management Zimbabwe. 1971.

51. Gaudchau MD. Report on control of Red- billed weaver bird quelea quelea in the republic of the Sudan. 1967.

52. Gadd P Jr. Use of the Modify ed Australian Crow (MAC) trap for the control of depredating birds in Sonoma county. In: Proceedings of the 17th vertebrate pest conference. University of California, Davis: 1996; 103-107.

53. Lowe KW. The Australian Bird Bander's Manual. Australian National Parks and Wildlife Service, Canberra. 1989.

54. Bishop J, McKay H, Parrott D, Allan D. Review of International research Literature Regarding the Effectiveness of Auditory Bird Scaring Techniques and Potential Alternatives. Department for Environment, Food and Rura Affairs, New York. 2003.

55. Sharp T, Saunders G. BIR002 Trapping of Pest Birds. NSW Department of Primary Industries and the Department of the Environment and Heritage. 2004.

56. GTZ. The ecology and control of the Red-billed weaver Bird Quelea Quelea L. in Northeast Nigeria. Special publication No. 199. Eschborn. West Germany: Deutsche Gesselschaft fur Technische Zusammenarbeit (GTZ). 1987.

57. Meinzingen WF. New Application Techniques. Internal report of FAO/ UNDP Regional Quelea Project RAF/81/023. Monitoring. In: Proceedings of Vegetation 2000, 2 years of operation to prepare the future, Lake Maggiore - Italy. 1984.

58. Marsh RE, Erickson WA, Salmon TP. Bird Hazing and Frightening Methods and Techniques. Other Publications in Wildlife Management. 1991.

59. Shefte NR, Bruggers RL, Schafer EN Jr. Repellency and Toxicity of 3 control chemicals to for species of Africa grain-eating birds. J Wildl Manage. 1982; 46(2): 453-457.

60. Mason JR, Clark L. Avian repellents: options, modes of action, and economic considerations. In: Repellents in Wildlife Management. National Wildlife Research Centre, Fort Collins, Colorado. 1997: 371-391.

61. FAO/DLCO-EA. Proceedings of the international conference on the quelea ecology, management, policy. Kenya. 1985.

62. Pope GG, Ward P. The Effects of Small Application of an Organophosphours Poison, Fenthion, on the Weaver bird, Quelea quelea. Pest Manag Sci. 1972; 3(2): 179-205. 